\title{
Spatially explicit estimation of forest age by integrating remotely sensed data and inverse yield modeling techniques
}

\author{
Ludovico Frate ${ }^{(1)}$, Maria Laura \\ Carranza ${ }^{(1)}$, Vittorio Garfi ${ }^{(2)}$, \\ Mirko Di Febbraro ${ }^{(1)}$, Daniela \\ Tonti ${ }^{(3)}$, Marco Marchetti ${ }^{(3)}$, \\ Marco Ottaviano ${ }^{(3)}$, Giovanni \\ Santopuoli ${ }^{(3)}$, Gherardo Chirici ${ }^{(4)}$
}

\begin{abstract}
We present an innovative method based on the application of inverse yield models for producing spatially explicit estimations of forest age. Firstly, a raster growing stock volume map was produced using the non-parametric kNearest Neighbors estimation method on the basis of IRS LISS-III remotely sensed imagery and field data collected in the framework of a local forest inventory. Secondly, species-specific inverted yield equations were applied to estimate forest age as a function of growing stock volume. The method was tested in 128000 ha of even-aged forests in central Italy (Molise region). The accuracy of the method was assessed using an independent dataset of 305 units from a local standwise forest inventory. The results demonstrated that the forest age map was accurate, with a root mean square error of 15.8 years $(30 \%$ of the mean of field values), and useful for supporting forest management purposes, such as the assessment of harvesting potential and ecosystem services. Thanks to the use of remotely sensed data and spatial modeling, the proposed approach is cost-effective and easily replicable for vast regions.
\end{abstract}

Keywords: k-Nearest Neighbors, Mapping, Forest Inventory, Growing Stock, IRS LISS-III
\& Dickson 1997), small mammals (Ecke et al. 2002), bats (Russo et al. 2010), beetles (Lassauce et al. 2013), lichens, fungi and bryophytes (Rambo \& Muir 1998, McGee \& Kimmerer 2002). Moreover, forest stand age affects vascular plant diversity (Halpern \& Spies 1995, Pitkänen 1997, Honnay et al. 1998, Deconchat \& Balent 2001). Therefore, it is important to identify the distribution patterns of forest stand age to understand and balance the benefits and drawbacks of different management scenarios which should be aimed at guaranteeing and maximizing ecosystem services provisioning in time (Forest Europe/UNECE/FAO 2011, Gamfeldt et al. 2013). The importance of forest age is officially acknowledged by its inclusion in the set of 35 $\square$ (1) Envix Lab, Dipartimento di Bioscienze e Territorio (DiBT), Università degli Studi del Molise, I-86090 Pesche, Isernia (Italy); (2) Global Ecology Lab, Dipartimento di Bioscienze e Territorio (DiBT), Università degli Studi del Molise, I- 86090 Pesche, Isernia (Italy); (3) Natural Resource \& Environmental Planning Lab, Dipartimento di Bioscienze e Territorio (DiBT), Università degli Studi del Molise, I- 86090 Pesche, Isernia (Italy); (4) geoLAB - Laboratorio di Geomatica, Dipartimento di Gestione dei Sistemi Agrari, Alimentari e Forestali (GESAAF), Università degli Studi di Firenze, I-50145 Firenze (Italy)

@ Maria Laura Carranza (carranza@unimol.it)

Received: Dec 12, 2014 - Accepted: Apr 14, 2015

Citation: Frate L, Carranza ML, Garfì V, Di Febbraro M, Tonti D, Marchetti M, Ottaviano M, Santopuoli G, Chirici G (2015). Spatially explicit estimation of forest age by integrating remotely sensed data and inverse yield modeling techniques. iForest 9: 63-71. - doi: 10.3832/ifor1529-008 [online 2015-07-25]

Communicated by: Matteo Garbarino
pan-European indicators (MCPFE 2001) routinely used to monitor and assess sustainable forest management in Europe (MCPFE 2002, MCPFE/UNECE/FAO 2007, Forest Europe/UNECE/FAO 2011). Consequently, accurately and spatially estimating forest stand age is essential in order to support environmental assessment and forest monitoring programs at a variety of spatial scales (McRoberts et al. 2011). The interest in the spatial reconstruction of the forest age patterns in Europe is demonstrated by at least three recent studies. Bellassen et al. (2011) used the ORCHIDEE-FM processbased vegetation model to reconstruct past age-class distributions in the period 1950-2000. Seidl et al. (2011) used the matrix approach of EFISCEN (Schelhaas et al. 2007), developing a simple age-class distribution back-casting method. Vilén et al. (2012) combined historical inventory data with a back-casting method to reconstruct the forest age structure in Europe in the period 1950-2000. However, these studies have produced low-resolution $\left(0.25^{\circ}\right)$ forest age maps which are only useful when aggregated at national level.

The aim of our study is to propose a simple and straightforward method for the high-resolution (pixel size of $20 \mathrm{~m}$ ) spatial estimation of forest age, integrating plotlevel forest inventory data with remotelysensed imagery through the application of inverted yield models. Such an approach could be easily implemented to create the age structure at a given time, useful for a high-resolution application of the method proposed by Vilén et al. (2012) or other approaches based on the detection of fo- 
rest disturbances (Kennedy et al. 2010).

National Forest Inventories (NFIs) are the primary data source of national and large area assessments for international forest resource reporting ( $M c$ Roberts et al. 2009). A questionnaire developed within the COST Action E43 ("Harmonisation of National Forest Inventories in Europe: Techniques for Common Reporting") revealed that forest age is currently estimated in the $96 \%$ of the European NFIs (Chirici et al. 2012a). However, age definitions, sampling designs and protocols, make age data harmonization and aggregation across countries very difficult (Chirici et al. 2012a).

The provisioning of low cost and widely available remotely-sensed data has added a spatial component to forest attribute information acquired in the field by forest inventories through the construction of maps. McRoberts \& Tomppo (2007) presented a review of the methods used for integrating remotely-sensed data into NF projects. According to the review by $\mathrm{McRo}$ berts et al. (2010), the methods for constructing maps based on plot-level NFI data can be distinguished on the basis of several factors. Forest categorical (e.g., forest types) or continuous (e.g., growing stock volume) variables can be estimated with supervised or unsupervised approaches, the estimates can be provided at pixel level or for aggregated areas, and parametric or non-parametric algorithms can be used.

Although a number of successful applications of parametric approaches exists for the estimation of forest variables, the nonparametric k-Nearest Neighbors (k-NN) method successfully emerged as the most popular in the last years, at least when forest inventory data is used. Commonly estimated forest variables include growing stock volume and forest type, while commonly used, remotely-sensed variables in clude optical spectral bands, radar information and, increasingly in the last decade, airborne laser scanning metrics.

With respect to the very large number of studies related to the spatial estimation of more traditional forest variables (such as growing stock volume or biomass) a relatively low number of experiences are available in literature for stand age estimation and mapping. Stand age maps can be pro duced by adopting multi-temporal or single-temporal approaches. Multi-temporal methods date forest stands accounting for the years since the last natural or anthropogenic disturbance. Several examples of this so-called temporal trend analysis (Kennedy et al. 2010), which is usually based on the integration of optical satellite data and ancillary information, do exist (e.g., Zhang et al. 2004 for Canada and Pan et al. 2010 for North America).

Single-temporal approaches are aimed at predicting the age of forest stands at a given date without reconstructing past disturbances, using remotely sensed images acquired on one date only. In these works, the stand age or the stand age classes are measured or acquired in the field in a sample of the forest (plots or stands). When categorical age classes have to be predicted and mapped, parametric (such as the well-known maximum likelihood - Nel et al. 1994), or non-parametric algorithms (such as neural networks - Kimes et al. 1996) can be used. The spectral values of the different bands of a multispectral satellite sensor are used as raw predictors, or transformed through the calculation of vegetation indexes or manipulated with moving window filters. As for the multitemporal approach, predictors from remotely sensed data are frequently coupled with ancillary layers, such as those created on the basis of a Digital Elevation Model (Kimes et al. 1996).

Contrastingly, when continuous values of forest age have to be estimated, the most common approach is based on the use of the non-parametric k-Nearest Neighbor algorithm (Holmström \& Fransson 2003, Reese et al. 2003). In these cases, stand age is measured in sample plots in the framework of a formal forest inventory.

This approach has two main limitations. Firstly, in forest inventories plot-level forest stand age is usually calculated by examining tree rings from cores of selected trees. This can lead to inaccurate estimations since only one or a few trees for each plot may be cored in the field for reducing costs (Pan et al. 2010). Secondly, several definitions of stand age are adopted in Europe, thus data from different National Forest Inventories adopting different definitions cannot be directly aggregated. Chirici et al. (2011) report that some of the most used definitions for stand age are: (i) the mean age of the trees in the upper (dominant) tree layer; (ii) the mean tree age of the dominant species (in the upper layer); or (iii) the mean age of all trees weighted with basal area or crown cover.

For the above reasons, we think that a method for deriving a spatial estimation of forest stand age with no direct use of the forest age information acquired by the NFIs in the field would be useful, especially within a pan-European context when the information from different NFIs plots should be merged.

In this study, we propose a simple approach based on the integration of remotely sensed data and inverted yield models. We tested the method on even-aged forests located in a study area covering the administrative region of Molise (central Italy). The method consists of three sequential steps. First, a high resolution growing stock volume map is produced by integrating optical remotely sensed imagery from IRS LISS-III and field data from a local forest inventory, using the well-known k-NN method. Second, inverted yield equations were developed for each one of the evenaged forest categories in the study area, in order to predict the forest stand age as a function of the growing stock volume.
Third, the forest age map was obtained by applying forest-category-specific inverted yield equations to the growing stock volume map, and its accuracy was evaluated using independent information available in local standwise forest inventories created for supporting forest management at a local level.

\section{Materials}

\section{Study area and input data}

The study area, coincident with the administrative region of Molise (central Italy), covers approximately 443758 ha (Fig. 1) and is characterized by remarkable environmental heterogeneity with altitudes ranging from the sea level (Adriatic coast) in the east to $2050 \mathrm{~m}$ a.s.l. at the Matese massif in the south. The climate of this region varies from Mediterranean to temperate (Garfì \& Marchetti 2011).

Forests and other wooded lands cover $35 \%$ of the region and are dominated by deciduous broad-leaved formations (Garfì \& Marchetti 2011). Turkey oak forests (Quercus cerris) represent the most common forest type in this region, covering $40 \%$ of the total forest area. In some hilly warm sectors, downy oaks (Quercus pubescens) dominate the forest landscape (22\% of forests). In mountain sectors (above $1200 \mathrm{~m}$ a.s.l.) and at colder sites, deciduous oak forests are replaced by beech forests (Fagus sylvatica $-9.5 \%$ of the forest area). Other forest categories which are less represented include the hop-hornbeam forests (Ostrya carpinifolia), holm oak forests (Quercus ilex) and chestnut forests (Castanea sativa). The autochthonous silver-fir forest (Abies alba, $0.3 \%$ of the forest area) is of particular interest because it represents a post-glacial relict that only survives in small areas of the Apennines (Lombardi et al. 2012, Santopuoli et al. 2014). Most forests in this region are even-aged (128 402 ha, approximately $80 \%$ of the total forest area in the region), and are mainly managed as coppice for the production of firewood. In unmanaged areas, open formations and irregular structured forests (e.g., invasive broad-leaved forests and riparian forests) are also present (Garfì \& Marchetti 2011).

In this study we used cloud free IRS LISS III imagery acquired in the summer of 2006 for predicting the growing stock volume. Imagery was obtained from the IMAGE2006 dataset (Müller et al. 2006). The imagery was characterized by several salient features: (i) geometrically and radiometrically corrected; (ii) nominal spatial resolution of 23.5 meters resampled at $20 \mathrm{~m}$ through a cubic convolution resampling and projected in WGS 84 UTM $32 \mathrm{~N}$; and (iii) four bands acquired between the green and near infrared wavelengths (0.52-0.59 $\mu \mathrm{m}, 0.62-0.68 \mu \mathrm{m}, 0.77-0.86 \mu \mathrm{m}, 1.55-1.70$ $\mu \mathrm{m})$. A more detailed description is reported by Müller et al. (2006).

A map of the even-aged forest categories in the region was obtained from a fine 
Fig. 1 - Map of the even-aged forest categories extracted from the Forest Types map. The hexagonal systematic grid used for the Regional Forest Inventory is represented. The black dots represent the locations of the 304 sampling units which were used for estimating the growing stock volume in this study.

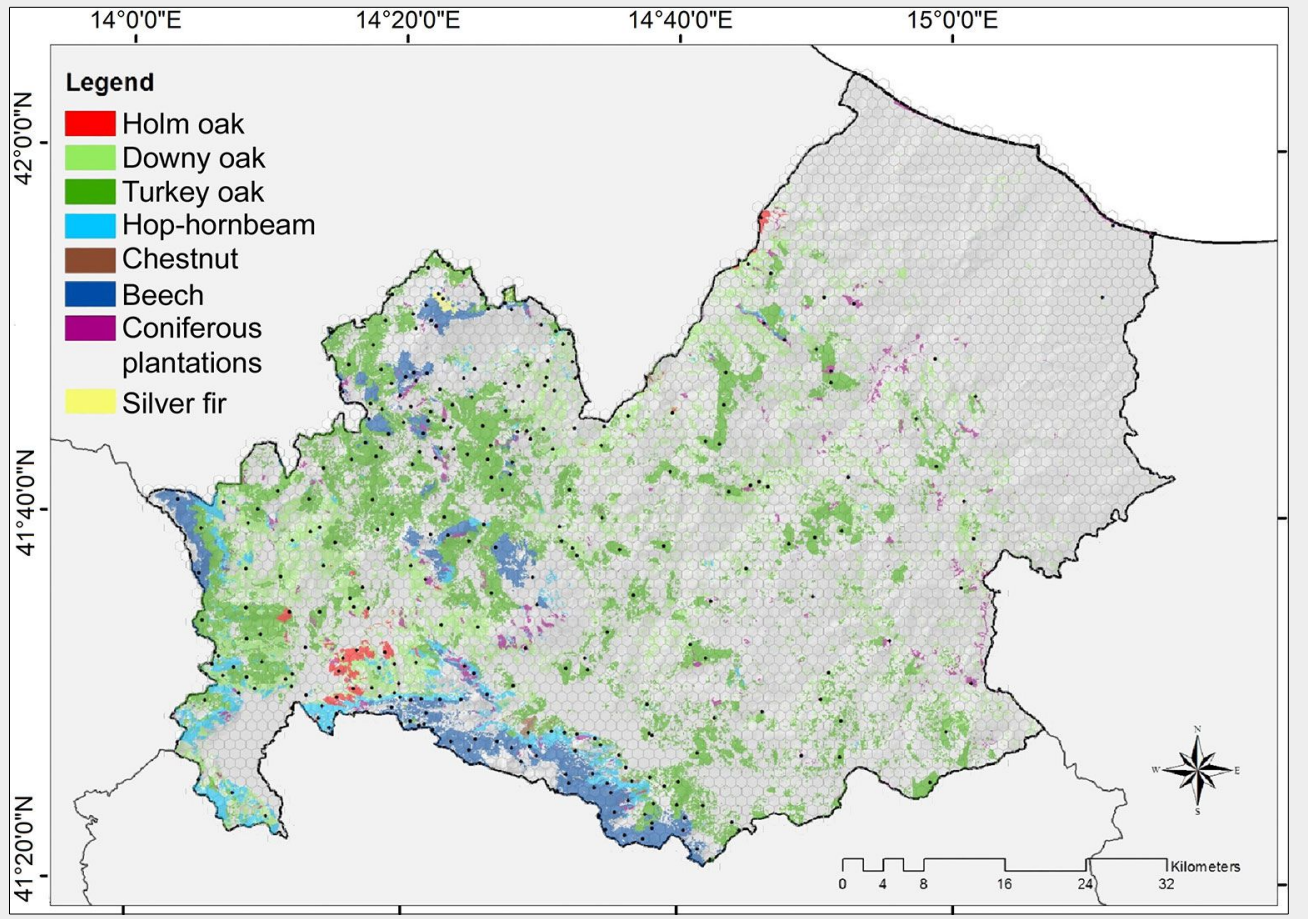

scale (1:10.000) map of forest types (Garfì \& Marchetti 2011). We selected the following eight even-aged categories: (i) holm oak forests; (ii) downy oak forests; (iii) hop-hornbeam forests; (iv) chestnut forests; ( $v$ ) turkey oak forests; (vi) beech forests; (vii) coniferous plantations (coastal/plain coniferous plantations and mountainous/sub-mountainous coniferous plantations); (viii) silver-fir forests (Fig. 1). Geocoded field data regarding the growing stock volume was collected in the framework of a regional Forest Inventory carried out in 2006. The Forest Inventory was conducted using a standard two-phase tessellated random-stratified sampling (TSS) design (see Cochran 1977 and Fattorini 2003 for details). All tree stems with a diameter at breast height $(\mathrm{DBH})$ greater than $3 \mathrm{~cm}$ were calipered in 304 circular plots having a radius of $13 \mathrm{~m}$. In addition, tree height was measured for a subsample of these trees following the Italian National Forest Inventory protocol (INFC 2006) and then estimated for the rest of the trees. For each sampling unit, the growing stock volume was calculated using allometric equations which were based on stem DBH and height (Castellani et al. 1984).

\section{Inverted yield models}

Yield refers to the final dimensions of a forest variable (e.g., growing stock volume or annual increment) at the end of a certain period (Vanclay 1994). In even-aged stands, yield equations predict the growing stock volume $(G S)$ at a specified age (eqn. 1):

$$
G S=f(\text { age })
$$

As a consequence, an inverted yield equation can be used to estimate the forest stand age as a function of growing stock (eqn. 2):

$$
\text { age }=f(G S)
$$

Here, for each even-aged forest category, we selected a yield equation specifically developed for the Molise region or, when this was not available, we selected an equation build up for different areas in central Italy having forest stand characteristics similar to those of the study area. Next, the yield equations ( $G S$-age functions) were inverted to determine the age at a given $G S$ volume (inverted yield equations). A full description of the equations used in this study is reported in the Appendix 1.

\section{Local standwise forest inventories}

To assess the accuracy of the forest growing stock volume and stand age spatial predictions, we used an independent dataset containing information about the growing stock and stand age. To this purpose, we created a geodatabase by aggregating 21 local standwise forest inventories which were available in the study area. The information in these inventories is available for each forest stand. The growing stock volume in the forest management units was measured on the basis of specific sample plots or on the basis of full calipering. Stand age was measured as the number of years from the last disturbance (in most of the cases the last harvesting event). This information was considered free of errors for the subsequent steps of our work.

The information recorded in the plans refers to the year of plan preparation. We updated the growing stock volumes to 2006 (the same of satellite images), using the mean annual increments derived from the yield models. The forest age of each forest unit was also updated by adding the number of years intervening between the year of preparation of the inventory and the year 2006. Finally, we excluded all management units with silvicultural interventions occurred between the plan date and the year 2006. Overall, the growing stock volume information was available for 446 stand units, covering an area of 4959 ha, and ranging in size between 0.14 and 52 ha (with a standard deviation of almost $8 \mathrm{ha}$ ) The mean actualized growing stock volume per stand unit was $2746.24 \mathrm{~m}^{3}\left(237 \mathrm{~m}^{3} \mathrm{ha}^{-1}\right)$ and varied between a minimum of $7.02 \mathrm{~m}^{3}$ $\left(10 \mathrm{~m}^{3} \mathrm{ha}^{-1}\right)$ and a maximum of $16670 \mathrm{~m}^{3}$ $\left(673 \mathrm{~m}^{3} \mathrm{ha}^{-1}\right)$ with a standard deviation of $2792 \mathrm{~m}^{3}\left(144 \mathrm{~m}^{3} \mathrm{ha}^{-1}\right)$. Data regarding forest stand age was available for 305 stand units covering 3137 ha. The mean stand age referred to the year 2006 was 52 years, varying between 1 and 127 years (standard deviation of 35 years).

\section{Methods}

Forest age was mapped following the general framework outlined in Fig. 2, first by spatially estimating the growing stock volume using the k-NN method, and then by applying the inverted yield models to derive the forest stand age.

\section{Growing stock map}

The non-parametric multivariate k-Nearest Neighbor (k-NN) method was used to spatially estimate the growing stock volume by combining the data acquired at the 304 field plots of the local forest inventory with the IRS LISS III multispectral images (Chiavetta et al. 2008, Lasserre et al. 2011). We estimated the growing stock for each IRS LISS III pixel $\left(G \hat{S}_{\mathrm{t}}\right)$ as follows. The reference pixel set $(r)$ is those for which the IRS LISS III spectral values and the growing 


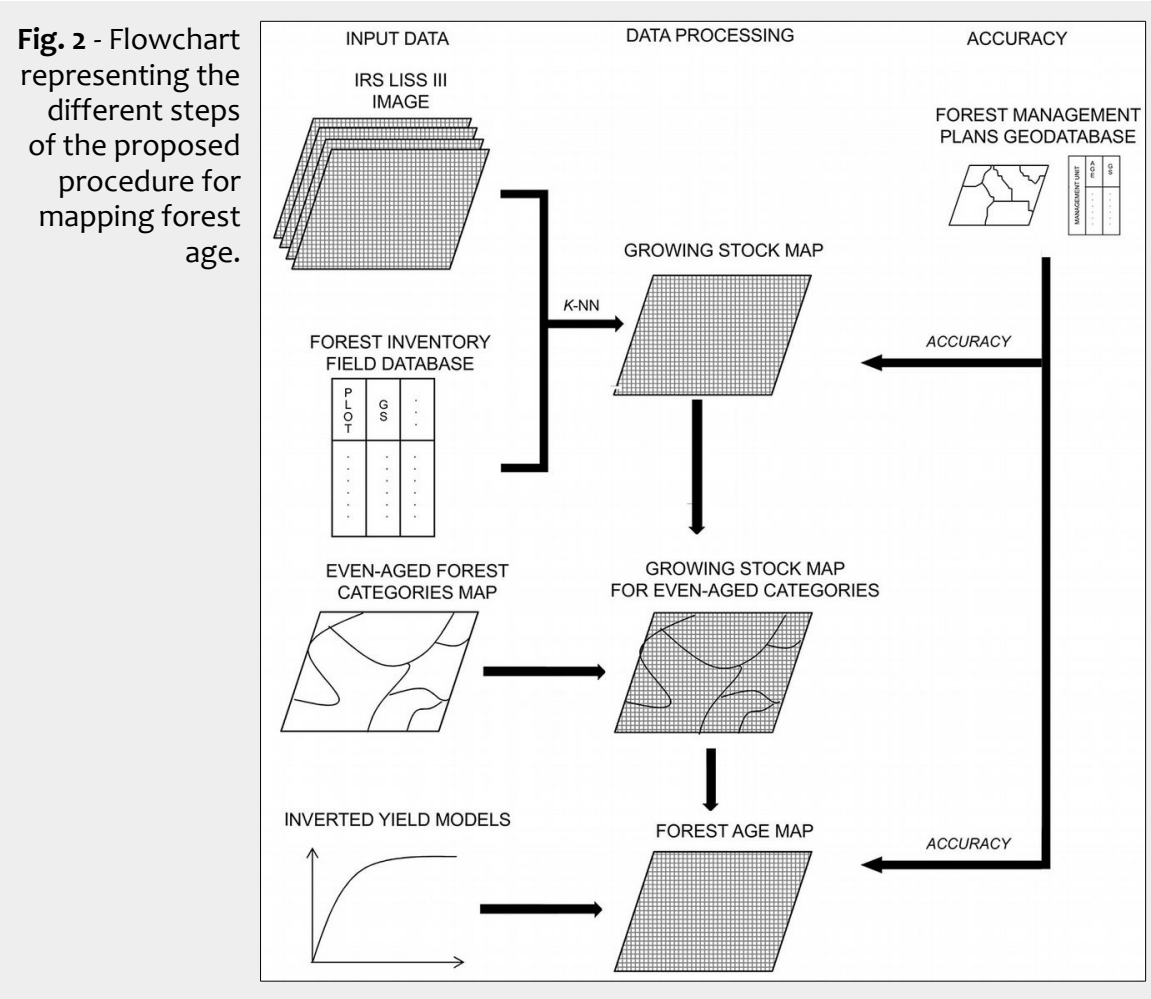

stock values $\left(G S_{\mathrm{r}}\right)$ observed in the field 3210050 pixels), and the reference was were available, while the target pixels $(t) 304$ pixels, belonging to the field plots of are those for which the spectral values the local forest inventory. The estimates were available and the growing stock vo- were calculated using the K-NN FOREST lume (denoted as the target variable $G S_{t}$ ) free software (Chirici et al. 2012b). We had to be estimated (eqn. 3):

$$
\hat{G S}=\frac{\sum_{r=1}^{k} W_{t, r} G S_{r N N}}{\sum_{r=1}^{k} W_{t, r}}
$$

where $G S_{\text {rNN }}$ represents the growing stock values for the pixels located in the k-Nearest Neighbor sampling units of the target pixel $t$ and $W$ is a weight factor which is inversely related to the distance between the pixel $t$ and the nearest $r$ measured on the fourth dimensional IRS LISS III spectral band space (Chirici et al. 2008). Here, the target set was made of the IRS LISS III pixels belonging to the even-aged forest area (128 402 ha corresponding to tested three different distance measures implemented within the K-NN FOREST software (Euclidean, Mahalanobis and Fuzzy), with $k$ values ranging from 1 to 10 based on the averaged spectral values of a $3 \times 3$ pixels area surrounding the field plots (Chirici et al. 2008). The Leave-One-Out (LOO) approach (Fazakas et al. 1999, Chirici et al. 2012b) was used to test several k-NN configuration, achieving the most accurate estimation using the Euclidean distance with $k=6$.

For a more detailed description of the $\mathrm{k}$ $\mathrm{NN}$ algorithm and the assumptions and the implications related to its use, we refer to the vast bibliography available (Chirici et al. 2008, Baffetta et al. 2009, McRoberts 2009).

\section{Forest age map}

The forest age map was derived on the basis of the growing stock volume map, the map of forest types and the respective inverted yield equations. For each pixel belonging to one of the eight even-aged forest categories considered, we calculated the forest age as a function of growing stock volume by applying the specific inverted yield equations reported in the Appendix 1.

\section{Accuracy assessment}

To test the accuracy of the produced maps (firstly growing stock volume and secondly the stand age), the per-pixel estimated values were averaged for each one of the stand units from the standwise forest inventories (446 units for the growing stock volume and 305 units for the stand age). Next, the average values estimated per units were compared against the fieldrecorded data by calculating the Pearson's correlation coefficient and the Root Mean Square Errors (RMSE) both in absolute and relative terms.

\section{Results}

The growing stock volume was accurately estimated through the k-NN process, as the Pearson's correlation coefficient between estimates and field recorded values per management unit was 0.98 , with a RMSE of $22 \%$ (Fig. $3 a$ ). The estimated mean volume per management unit was $2715 \mathrm{~m}^{3}$, with a range of $0.001-16724 \mathrm{~m}^{3}$ and a standard deviation (SD) of $2855 \mathrm{~m}^{3}$.

The forest age map (Fig. 4) also resulted accurate (Fig. 3b), with a correlation between estimated and observed age (per forest management unit) of 0.928 and a RMSE of 15.78 years (30\% of the real values). The estimated forest age per-pixel varied between 1 and 200 years, with a mean of 33 years ( \pm 24 SD - Fig. 5 ).

Beech and autochthonous silver-fir forests resulted as the oldest formations, with average ages of $56 \pm 24$ and $46 \pm 10$ years, respectively. In contrast, chestnut forests ( $15 \pm 8$ years) resulted the youngest forests. The downy oak forests and coniferous plantations were relatively young with $19 \pm 21$ and $20 \pm 9$ years, respectively. The
Fig. 3 - Correlation between the predicted and observed (for 446 stand units) total growing stock volume (a) and average age (b). The bold lines represent $y=x$. Dashed lines indicate the $95 \%$ confidence intervals.

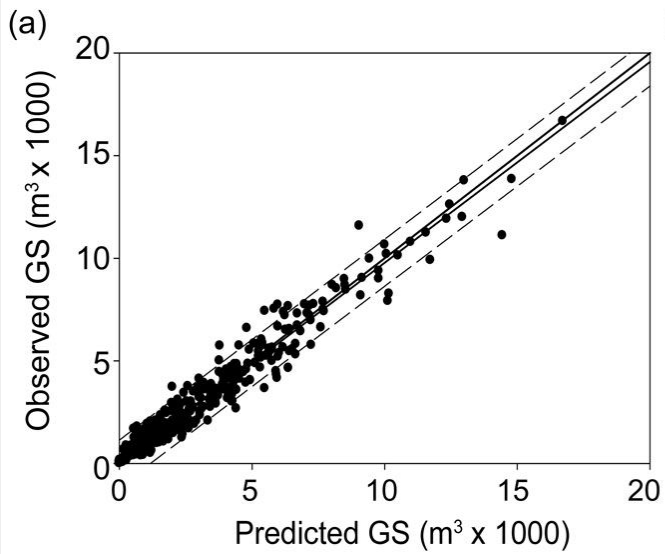

(b)

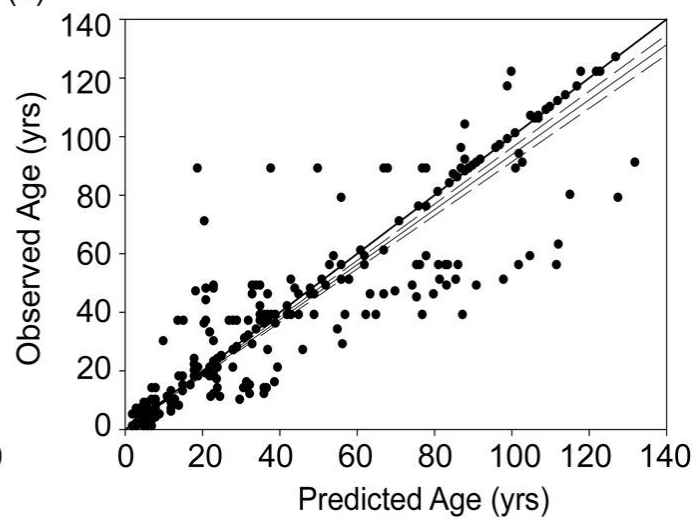


Fig. 4 - Forest age distribution in the Molise region for even-aged categories.

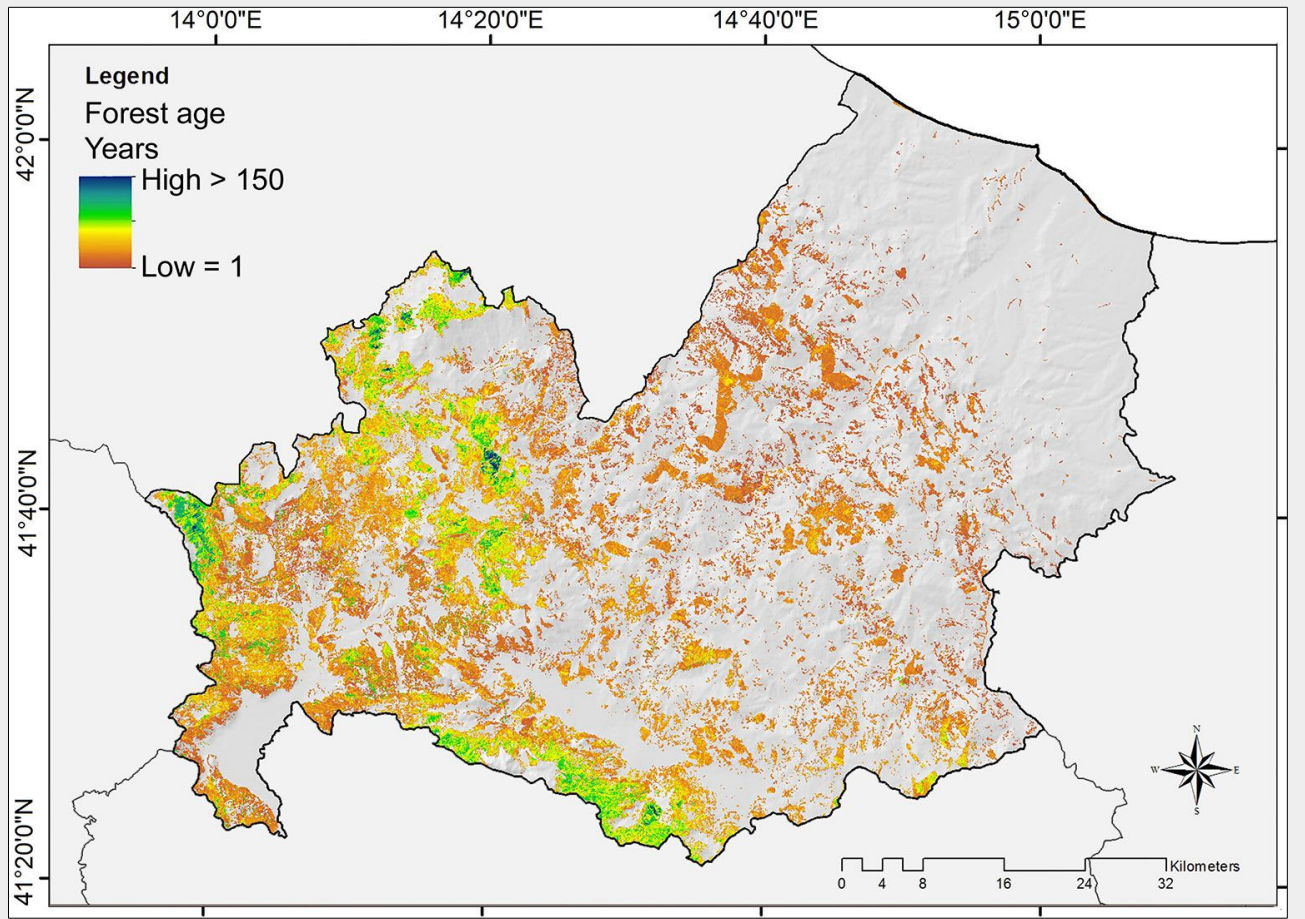

remaining deciduous broadleaved forests (Holm and Turkey oaks, and Hop-hornbeam forests) had mean ages similar to the entire forested area $(35 \pm 20,37 \pm 23$ and 28 \pm 18 , respectively).

After subdividing the forest age map in ten-year classes, we found that $34 \%$ of the investigated forests were less than 20 years old, $60 \%$ were between 20 and 80 years old and only the $6 \%$ of the forests were older than 80 years (Fig. 6). Only $0.56 \%$ of the forests were older than 120 years and only $0.29 \%$ older than 140 years. The oldest age class (190-200) was rare, with a percentage of $0.02 \%$. The dominant age classes were 10-20 and 20-30, representing approximately $43 \%$ of the investigated forested area. Some forests were mainly distributed in young formations within the region. For example, most coniferous plantations were younger than 10 years, while the downy oak forests and the chestnut forests were largely represented by stands of 10 to 20 years. Turkey oak, hop-hornbeam and holm oak forests were more abundant in the young-middle-aged classes (10-40 years) and were less represented in older stands. For turkey oak and hop-hornbeam forests, the age class of 2030 years was dominant, while 30-40 years was the dominant age class for the holm oak forests. Beech forests follow a bellshaped distribution with the majority of forests occurring in the age group of 30-70 years and a maximum age group of $60-70$ years. In contrast, most silver fir forests were between 50 and 60 years old, though some younger stands were present.

\section{Discussion}

The relatively young age of the mapped forests ( $43 \%$ of the forest area in our study ranges between 10 and 30 years) reflects the management practices in the studied region, where coppice with short rotation periods (usually less than 25 years) is the most common silvicultural system for broadleaves (Ciancio et al. 2006). This management type is widespread over the Italian peninsula, particularly along the Apennines, and accounts for approximately 3.9 million of hectares, almost $40 \%$ of the total forest area in Italy (INFC 2005). Contrastingly, approximately $0.5 \%$ of the forests in
Fig. 5 - Mean estimated forest age (white circle) for the eight even-aged forest types with their respective standard deviations (whiskers). The continuous horizontal line refers to the average age of forests in the region, while the dashed lines represent the regional standard errors. The grey bars represent the area (in ha) covered by each forest type.

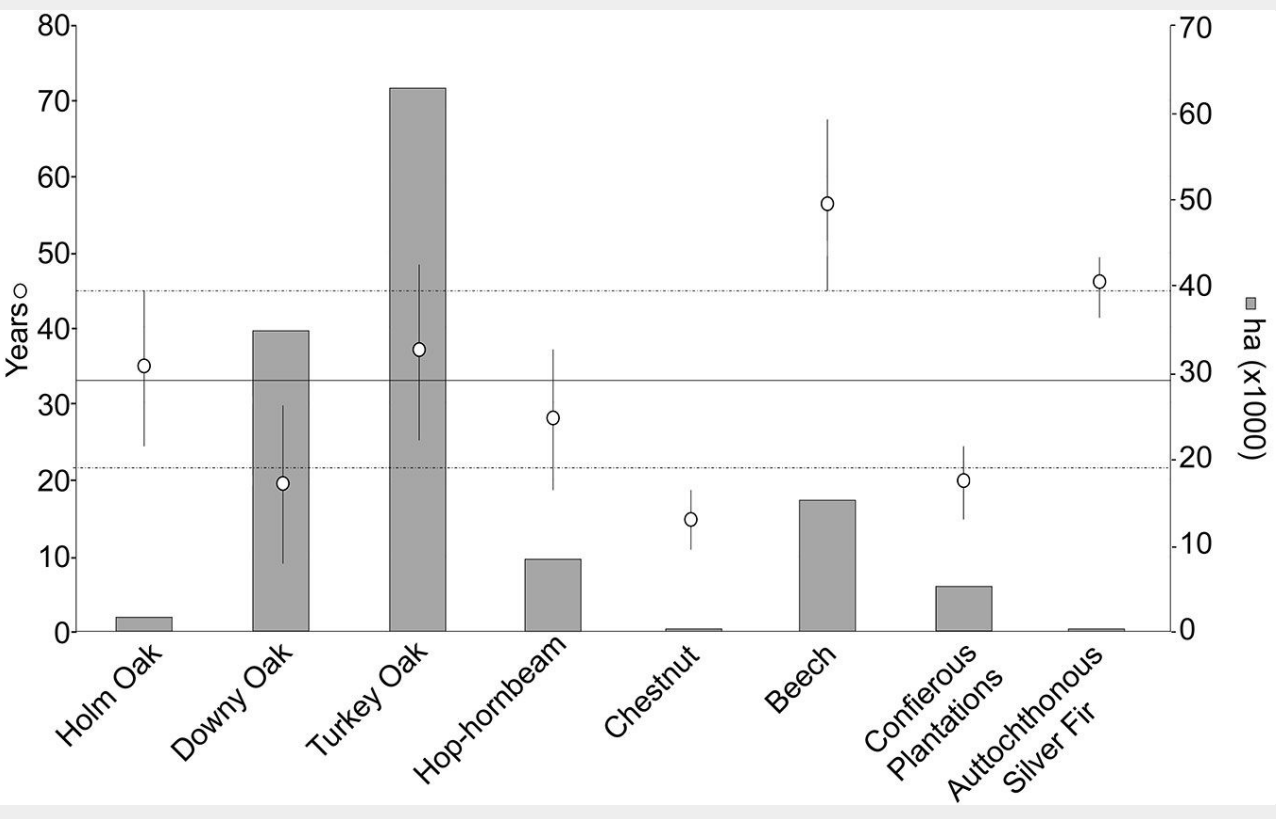




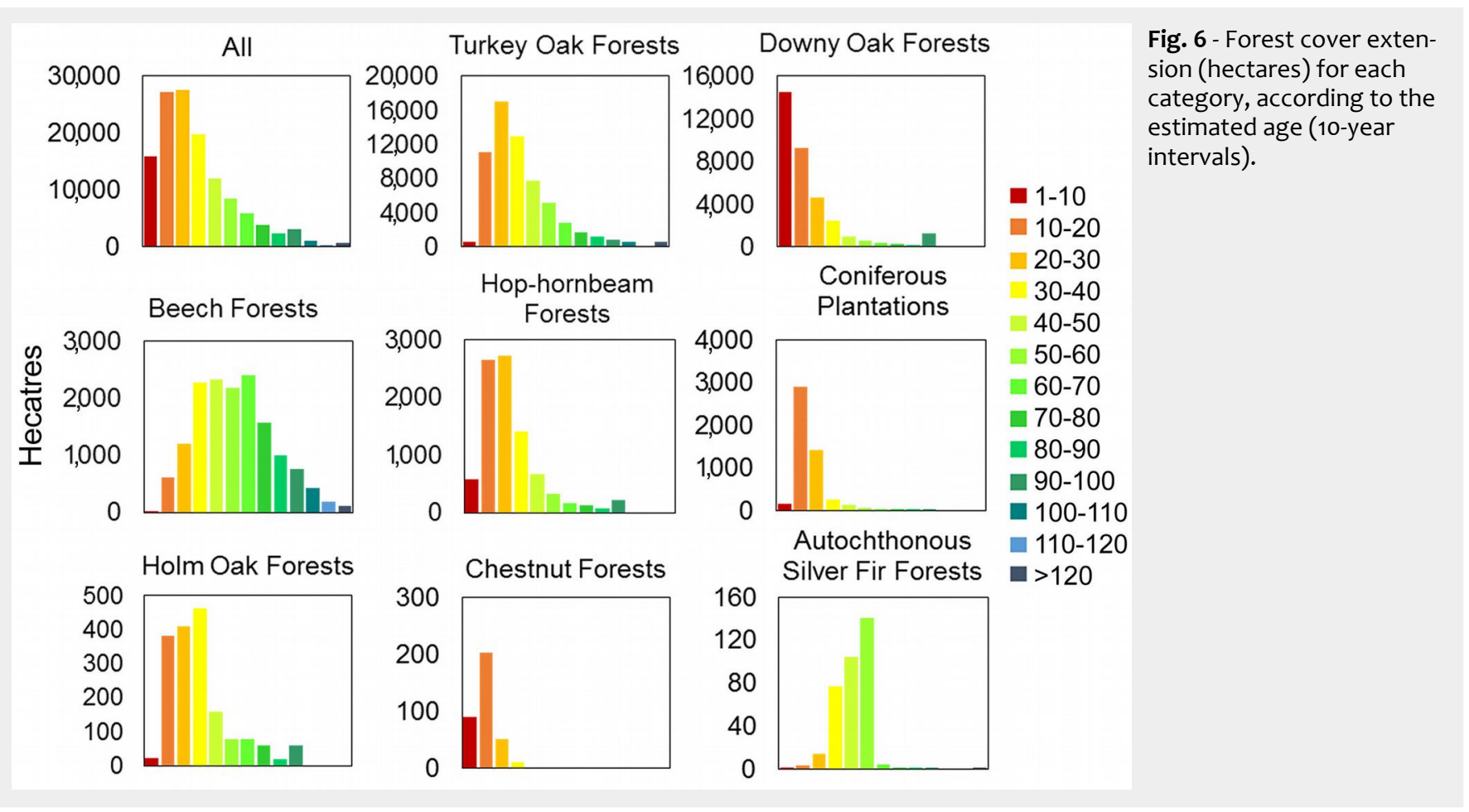

the study region are older than 140 years (mainly represented by beech and turkey oak forests). Although such percentage is lower than that reported for Central European forests (Forest Europe/UNECE/FAO 2011), it will likely increase in the near future, mainly as a consequence of the abandonment of traditional harvesting and silvicultural practices which progressively occurred since the end of the second World War. Indeed, a gradual increase in forest age (Vilén et al. 2012), cover (Gold et al. 2006, Frate \& Carranza 2013), and growing stock volume (Spiecker et al. 1996) was already observed in Europe.

The oldest formations in the study area are beech forests, mainly managed by the shelterwood system and only marginally as coppices with longer rotation periods (3040 years) as compared with other broadleaves. Such areas are mainly located in the less accessible upper mountain belt, where traditional silvicultural activities were abandoned as a result of depopulation and socio-economic changes. Consequently, these older beech forests are undergoing natural evolution (Ciancio et al. 2006, Carranza et al. 2012, Maesano et al. 2014). Furthermore, the conversion of coppices into high forests has been implemented in the last few decades in hilly and mountainous Mediterranean beech forests to attenuate the negative effects of frequent clearcuttings on the soil, landscape and biodiversity (Ciancio et al. 2006, Nocentini 2009). This will also contribute to increase the forest age in the next future across the studied area.

On the contrary, oak forests were relatively younger as a result of the traditional coppicing (clearcut with rotation period of 18-25 years) extensively applied for fuel wood production (Ciancio \& Nocentini 2004). However, turkey oak forests tend to be older than downy oak forests in the study area. In fact, turkey oak typically grows in hilly and sub-mountain areas, where coppice stands lost their economic importance and were abandoned to natural evolution or even converted to high forests (Nocentini 2009). These less accessible stands are now ageing and resulted older than their traditional rotation period (more than 25 years). Contrastingly, downy oak forests are located in the hilly sector of the Mediterranean bioclimatic zone, where the anthropic exploitation is more intense due to their easier access (Carranza et al. 2003, Acosta et al. 2005). These forests are regularly clear-cut, and consequently old stands are not present.

Both Holm oak and hop-hornbeam forests, which were traditionally grazed or coppiced for coal and fuel wood production (Carranza et al. 2003), are currently present in the studied area with young and middle aged stands. As in the cases of oak forests, young stands are located in more accessible areas, while older stands are typically limited to less accessible and remote districts.

Young and small coniferous plantations dominated by Pinus nigra and Pinus pinaster are widespread in the Molise region. Coniferous plantations were introduced in the 1960 s, mainly for protecting against soil erosion (Garfì \& Marchetti 2011). It is likely that the stand age map produced in this study underestimated the real age of such forests as they were planted on very poor and rocky soils, thus leading to a diminished stand growth rate. As a consequence, their current standing volume is probably lower that that expected based on the application of the yield models adopted in this study.

Chestnut forests were generally very young (between 10 and 20 years) and of limited extent (less than $360 \mathrm{ha}$ ). In the region, chestnut is mainly managed as coppice (frequently with short rotation periods of less than 20 years) for wood pole production (Garfì \& Marchetti 2011). Finally, autochthonous silver fir forests have a very limited extension in the region (less than $350 \mathrm{ha}$ ) and were mainly present in middleaged classes, revealing their past management history based on clear-cuttings. Nowadays, the traditional forest management of these pure Abies alba stands is abandoned both for the lack of economic interest in their wood assortments (Santopuoli et al. 2014) and their high conservation value (Maesano et al. 2014). For the above reasons, the age of these stands will likely increase in the future as a result of their current natural evolution.

In this study we produced a forest age map through the application of inverted yield models to a growing stock volume map created by integrating field data and remotely-sensed images though the k-NN method. The final map of forest stand age showed a good accuracy, giving an overall RMSE of $30 \%$ which is in line with previous experiences developed for mapping forest variables (Reese et al. 2003, McRoberts et al. 2010). The method we propose does not use stand age measurements acquired in the field. Age maps produced from detailed inventory data (Reese et al. 2003) and different source of data containing information on historical forest disturbance (Pan et al. 2010) may have high accuracy. However, such methods may be not implemented in areas where spatially distributed 
inventory plots are not available, as well as where inconsistencies between different data source exists, or when forest age is not provided by national or local inventories (McRoberts et al. 2009). In order to avoid these inconsistencies, in this work stand age was instead calculated on the basis of growing stock volume, which is a fairly well standardized variable across different countries, or at least it can be easily harmonized (McRoberts et al. 2009). As a consequence, our approach can be used for aggregating plot level information from NFIs of different countries, avoiding the problem of merging stand age information which refer to different definitions (McRoberts et al. 2011).

First attempts to construct forest age map in European countries have been carried out (Bellassen et al. 2011, Seidl et al. 2011, Vilén et al. 2012). Although these studies were extremely useful in depicting forest age structure in Europe, the achieved results were mainly useful when aggregated at national level. For example, the maps produced by Vilén et al. (2012) were in fact very coarse as for their spatial resolution $\left(0.25^{\circ}\right)$, being based on the simplistic assumption of a homogenous distribution of all age classes over the forest area in a country. In other words, the distribution of forest age classes available from National Forest Inventories of a given country are considered invariant in all the forest area of that country. On the contrary, our map has a geometric resolution of $20 \mathrm{~m}$ and could be a useful tool for planning local forest management actions. Nevertheless, it is advisable to use the produced forest age map at much coarser level since k-NN estimations could have a low pixel based accuracy (Reese et al. 2003). However, in our case the map accuracy (and thus its usefulness) dramatically improve when the estimations are aggregated over larger areas such as stands or management levels. In this respect and despite the limitations due to the use of an opportunistic database for accuracy assessment (e.g., nonprobability sampling design - Olofsson et al. 2014), the use of local standwise forest inventories was considered acceptable here for the following reasons: (i) the dataset is entirely independent from the dataset used for $G S$ map production; and (ii) it is cost-effective (Olofsson et al. 2014).

A stand age high-resolution map may have different uses. Firstly, such information can provide a sound basis for orienting forest management strategies, such as facilitating a general assessment of harvesting potential, identifying suitable stands to be promoted to natural evolution, or contributing to determining the optimal forest management strategies and maximizing the productivity of different ecosystem services. Secondly, forest age maps provide important, quantitative information supporting the assessment of carbon sequestration of forest ecosystems and their role in biogeochemical cycles (He et al. 2012). For example, younger stands are expected to exhibit a rapid increase in Net Primary Productivity (NPP), while older stands are expected to exhibit a slow decline. In this case, the availability of forest age spatial distribution patterns could be useful for assessing potential changes in the NPP under different management scenarios. Thus, potential changes in important ecosystems services which are directly associated with NPP, such as carbon sequestration, water cycling and regulation, soil fertility, local climate and air quality, could be assessed (Zurlini et al. 2014). Stand age distribution patterns could provide relevant information for monitoring biodiversity and in general for restoring more favorable conditions in old and evenaged forests (Burrascano et al. 2013). Finally, the proposed method could be a useful tool for supporting the implementation of forest management strategies in those regions where land ownership fragmentation (Pettenella et al. 2005) or the limited commercial value of timber production led to a lack of local management plans, as frequently occurs in Mediterranean areas.

The method we propose enlarges the range of applicability of yield models (Vanclay 1994), calling for the development of site-specific equations for main forest categories covering all the main biogeographical regions of Europe (Vuokila 1965, Peng 2000). Yield models were the oldest approach to yield estimations and their development was based on several assumptions that limit their range of applicability (Vuokila 1965, Weiskittel et al. 2011). For example, yield models assume that the age-volume relationship is valid for fully stocked or "normal" forest stands under specific stand site characteristics (e.g., soil fertility). When such models were locally unavailable for a specific forest type, those available for a neighboring region were adopted. All these issues lessen the accuracy of estimates. Future development of site-specific equations will likely enhance the proposed approach.

The main limitations of our approach is its suitability for age prediction of even-aged forests, which in any case represent the large majority of forests in the study area $(80 \%)$. Similarly, based on data from the last "State of Europe's forests" (Forest Europe/UNECE/FAO 2011) for 18 European countries (including the Russian Federation), even-aged forests represent the vast majority of European forests (almost 90\%, with more than 9 million of hectares). For such reason, the proposed method has a potential relevance for applications at the pan-European level.

\section{Conclusions}

In this study a simple and straightforward method for spatially estimating forest age was implemented through the application of inverted yield models to a growing stock volume map created by integrating field data and remotely-sensed images though the k-NN method. We produced a forest stand age map covering 128402 ha with an accuracy (RMSE of $30 \%$ ) which is in line with previous experiences developed for mapping forest variables.

The increasing development of Earth Observation techniques and the availability of forest inventories may probably lead to a more habitual derivation of forest variables maps in the near future. The procedure adopted in this study may be applied to European forests at continental scales on the basis of the information already available, for example based on the growing stock volume map from Gallaun et al. (2010), and the forest species map from Brus et al. (2012). This is particularly important as forest conservation across Europe requires a common approach to define and map forest age. Therefore, we advocate further studies to be conducted in the future to properly test and refine this procedure, with the aim of providing integrated information for increasingly larger areas.

\section{Acknowledgements}

This work was supported by the European Commission under the project by the LIFE+ ManFor C.BD (Life Environment Project LIFEog ENV/IT/000078) and by the Italian Ministry of University and Research in the framework of the following projects: "Development of innovative methods for forest ecosystems monitoring based on remote sensing" (PRIN2012 - grant no. 2012EWEY2S); CARBOTREE (PRIN2011 grant no. B21J12000560001); "Sviluppo di modelli innovativi per il monitoraggio multiscala degli indicatori di servizi ecosistemici nelle foreste Mediterranee" (FIRB2012 grant no. RBFR121TWX); and NEUFOR (PRIN2012 - grant no. 2012K3A2HJ]. We gratefully acknowledge two anonymous referees for valuable comments on the original version of the manuscript.

\section{References}

Acosta A, Carranza ML, Giancola M (2005). Landscape change and ecosystem classification in a municipal district of a small city (Isernia, central Italy). Environmental Monitoring and Assessment 108: 323-335. - doi: 10.1007/s10661-005-43 32-3

Baffetta F, Fattorini L, Franceschi S, Corona P (2009). Design-based approach to k-nearest neighbours technique for coupling field and remotely sensed data in forest surveys. Remote Sensing of Environment 113: 463-475. doi: 10.1016/j.rse.2008.06.014

Bellassen V, Viovy N, Luyssaert S, Le Maire G, Schelhaas MJ, Ciais P (2011). Reconstruction and attribution of the carbon sink of European forests between 1950 and 2000. Global Change Biology 17: 3274-3292. - doi: 10.1111/j.1365-2486. 2011.02476.x

Bradford JB, Birdsey RA, Joyce LA, Ryan MG (2008). Tree age, disturbance history, and carbon stocks and fluxes in subalpine Rocky Mountain forests. Global Change Biology 14: 2882-2897. - doi: 10.1111/j.1365-2486.2008.0168 
6.x

Brus DJ, Hengeveld GM, Walvoort DJJ, Goedhart PW, Heidema AH, Nabuurs GJ, Gunia K (2012). Statistical mapping of tree species over Europe. European Journal of Forest Research 131: 145-157. - doi: 10.1007/s10342-011-0513-5

Burrascano S, William S, Sabatini FM, Blasi C (2013). Commonality and variability in the structural attributes of moist temperate old-growth forests: a global review. Forest Ecology and Management 291: 458-479. - doi: 10.1016/j.for eco.2012.11.020

Carranza ML, Ricotta C, Fortini P, Blasi C (2003). Quantifying landscape change with actual vs. potential natural vegetation maps. Phytocoenologia 33: 591-601. - doi: 10.1127/0340-269X/20 03/0033-0591

Carranza ML, Frate L, Paura B (2012). Structure, ecology and plant richness patterns in fragmented beech forests. Plant Ecology and Diversity 5: 541-551. - doi: 10.1080/17550874.2012.74 0509

Castellani C (1972). Tavole stereometriche ed alsometriche costruite per i boschi italiani [Volume and yield tables for italian forests]. Istituto Sperimentale per l'Assestamento Forestale e l'Alpicoltura, Trento, Italy, pp. 429. [in Italian]

Castellani C, Scrinzi G, Tabacchi G, Tosi V (1984). Inventario forestale nazionale italiano. Tavole di cubatura a doppia entrata [Italian national forest inventory. Double-entry tree volume tables]. Ministero dell'Agricoltura e delle Foreste, Istituto Sperimentale per l'Assestamento Forestale e per l'Alpicoltura, Trento, Italy, pp. 65. [in Italian]

Chiavetta U, Chirici G, Lamonaca A, Lasserre B, Ottaviano M, Marchetti M (2008). Stima di attributi forestali tramite integrazione di dati inventariali e immagini telerilevate nell'Alto Molise [Estimation of forest attributes by integration of inventory and remotely sensed data in Alto Molise]. Italian Journal of Remote Sensing 40: 89-106. [in Italian] - doi: 10.5721/ItJRS20084 018

Chirici G, Barbati A, Corona P, Marchetti M, Travaglini $D$, Maselli $F$, Bertini $R$ (2008). Non-parametric and parametric methods using satellite images for estimating growing stock volume in alpine and Mediterranean forest ecosystems. Remote Sensing of Environment 112: 26862700. - doi: 10.1016/j.rse.2008.01.002

Chirici G, McRoberts R, Winter S, Barbati A, Brändli U-B, Abegg M, Beranova J, Rondeux J, Bertini R, Asensio IA, Cóndes S (2011). Harmonization tests. In: "National Forest Inventories: contributions to forest biodiversity assessments" (Chirici G, Winter S, McRoberts RE eds). Springer, Heidelberg, Germany, pp. 121-190. . doi: 10.1007/978-94-007-0482-4_5

Chirici G, McRoberts RE, Winter S, Bertini R, Brändli UB, Asensio IA, Bastrup-Birk A, Rondeux J, Barsoum N, Marchetti M (2012a). National forest inventory contributions to forest biodiversity monitoring. Journal of Forest Science 58: 257-268. - doi: 10.5849/forsci.12-003 Chirici G, Corona P, Marchetti M, Mastronardi A, Maselli F, Bottai L, Travaglini D (2012b). K-NN FOREST: a software for the non-parametric prediction and mapping of environmental variables by the k-Nearest Neighbors algorithm. Eu- ropean Journal of Remote Sensing 45: 433-442. doi: 10.5721/EuJRS20124536

Ciancio O, Nocentini S (2004). II bosco ceduo. Selvicoltura, assestamento, gestione [Coppices - Silviculture and forest management]. Accademia Italiana di Scienze Forestali, Firenze, Italy, pp. 721. [in Italian]

Ciancio O, Corona P, Lamonaca A, Portoghesi L, Travaglini D (2006). Conversion of clearcut beech coppices into high forests with continuous cover: a case study in central Italy. Forest Ecology and Management 224: 235-240. - doi: 10.1016/j.foreco.2005.12.045

Cochran WG (1977). Sampling techniques ( $3^{\text {rd }}$ edn). John Wiley and Sons, New York, USA, pp. 448.

Conner RN, Dickson JG (1997). Relationships between bird communities and forest age, structure, species composition and fragmentation in the West Gulf Coastal. Texan Journal of Science 49: 123-138. [online] URL: http://www. srs.fs.usda.gov/pubs/viewpub.php?index $=536$

Cornish PM, Vertessy RA (2001). Forest age-induced changes in evapotranspiration and water yield in a eucalypt forest. Journal of Hydrology 242: 43-63. - doi: 10.1016/S0022-1694(00) 00384-X

Costanza R, D'Arge R, De Groot R, Farberk S, Grasso M, Hannon B, Limburg K, Naeem S, O'Neill RV, Paruelo J, Raskin RG, Sutton P, Van Den Belt M (1997). The value of the world's ecosystem services and natural capital. Nature 387: 253-260. - doi: 10.1038/387253ao

Deconchat M, Balent G (2001). Vegetation and bird community dynamics in fragmented coppice forests. Forestry 74: 105-118. - doi: 10.1093/ forestry/74.2.105

Ecke F, Löfgren O, Sörlin D (2002). Population dynamics of small mammals in relation to forest age and structural habitat factors in northern Sweden. Journal of Applied Ecology 39: 781-792. - doi: 10.1046/j.1365-2664.2002.00759.x FAO (2012). State of world's forests 2012. FAO, Rome, Italy, pp. 60. [online] URL: http://www. fao.org/docrep/016/i3010e/i3010eoo.htm

Fattorini L (2003). A two-phase sampling strategy for forest inventories. In: "Advances in forest inventory for sustainable forest management and biodiversity monitoring" (Corona $\mathrm{P}$, Köhl M, Marchetti $M$ eds). Kluwer Academic Publishers, Dordrecht, The Netherlands, pp. 143-156. - doi: 10.1007/978-94-017-0649-0_12

Fazakas Z, Nilsson M, Olsson H (1999). Regional forest biomass and wood volume estimation using satellite data and ancillary data. Agricultural and Forest Meteorology 98- 99: 417-425. doi: 10.1016/S0168-1923(99)00112-4

Frate L, Carranza ML (2013). Quantifying landscape-scale patterns of temperate forests over time by means of neutral simulation models. International Journal of Geo-Information 2: 94109. - doi: 10.339o/ijgi2010094

Forest Europe/UNECE/FAO (2011). State of Europe's forests 2011: status and trends in sustainable forest management in Europe. Ministerial Conference on the Protection of Forests in Europe, FOREST EUROPE Liaison Unit Oslo, Oslo, Norway, pp. 337. [online] URL: http://www. foresteurope.org/documentos/State_of_Europ es_Forests_2011_Report_Revised_November_2 011.pdf
Gallaun H, Zanchi G, Nabuurs G-J, Hengeveld G, Schardt M, Verkerk PJ (2010). EU-wide maps of growing stock and above-ground biomass in forests based on remote sensing and field measurements. Forest Ecology and Management 260: 252-261. - doi: 10.1016/j.foreco.2009.10.011 Gamfeldt L, Snäll T, Bagchi R, Jonsson M, Gustafsson L, Kjellander P, Ruiz-Jaen MC, Fröberg $\mathrm{M}$, Stendahl J, Philipson CD, MikusiÅski G, Andersson E, Westerlund B, Andrén $H$, Moberg F, Moen J, Bengtsson J (2013). Higher levels of multiple ecosystem services are found in forests with more tree species. Nature Communications 4: 1340. - doi: 10.1038/ncomms2328 Garfì V, Marchetti M (2011). Tipi forestali e preforestali della regione Molise [Forest types of Molise Region]. Edizioni Dell'Orso srl, Alessandria, Italy, pp. 280. [in Italian]

Gold S, Korotkov A, Sasse V (2006). The development of forest resources, 1950 to 2000. Forest Policy and Economics 8: 183-192. - doi: 10.1016/j. forpol.2004.07.002

Halpern CB, Spies TA (1995). Plant species diversity in natural and managed forests of the Pacific Northwest. Ecological Applications 5: 913934. - doi: 10.2307/2269343

He L, Chen JM, Pan Y, Birdsey R, Kattge J (2012). Relationships between net primary productivity and forest stand age in US forests. Global Biogeochemical Cycles 26: 1-19. - doi: 10.1029/20 $10 \mathrm{~GB} 003942$

Holmström H, Fransson JES (2003). Combining remotely sensed optical and radar data in kNNEstimation of forest variables. Forest Science 49: 408-418. [online] URL: http://www.ingenta connect.com/content/saf/fs/2003/00000049/00 $000003 /$ art00008

Honnay O, Degroote B, Hermy M (1998). Ancient-forest plant species in western Belgium: a species list and possible ecological mechanism. Belgian Journal of Botany 130: 139154. [online] URL: http://www.jstor.org/stable/ 20794415

Kennedy RE, Yang Z, Cohen WB (2010). Detecting trends in forest disturbance and recovery using yearly Landsat time series: 1 . LandTrendr Temporal segmentation algorithms. Remote Sensing of Environment 114: 2897-2910. - doi: 10.1016/j.rse.2010.07.008

Kimes DS, Holben NB, Nickeson JE, McKee WA (1996). Extracting forest age in a pacific northwest forest from thematic mapper and topographic data. Remote Sensing of Environment 56: 133-140. - doi: 10.1016/0034-4257(95)00230-8 INFC (2005). Inventario nazionale delle foreste e dei serbatoi forestali di carbonio [Italian $\mathrm{Na}$ tional Forest Inventory, INFC]. Ministero delle Politiche Agricole Alimentari e Forestali, Ispettorato Generale - Corpo Forestale dello Stato, Consiglio per la Ricerca e Sperimentazione in Agricoltura, Unità di ricerca per il Monitoraggio e la Pianificazione Forestale (CRA-MPF), Trento, Italy, pp. 31. [in Italian]

INFC (2006). Procedure di posizionamento e di rilievo degli attributi di terza fase (con istruzioni per l'impiego degli applicativi $\mathrm{NAV}_{3} \mathrm{e}$ RAS3) [Procedures for positioning and surveying of third phase attributes]. CRA-MPF, Trento, Italy, pp. 292. [in Italian] [online] URL: http:// mpf.entecra.it/

Lassauce A, Larrieu L, Paillet Y, Lieutier F, Bouget 
C (2013). The effects of forest age on saproxylic beetle biodiversity: implications of shortened and extended rotation lengths in a French oak high forest. Insect Conservation and Diversity 6: 396-410. - doi: 10.1111/j.1752-4598.2012.00214.x Lasserre B, Chirici G, Chiavetta U, Garfì V, Tognetti R, Drigo R, Di Martino P, Marchetti $M$ (2011). Assessment of potential bioenergy from coppice forests trough the integration of remote sensing and field surveys. Biomass and Bioenergy 35: 716-724. - doi: 10.1016/j.biombioe.20 10.10.013

Lombardi F, Lasserre B, Chirici G, Tognetti R, Marchetti M (2012). Deadwood occurrence and forest structure as indicators of old-growth forest conditions in Mediterranean mountainous ecosystems. Ecoscience 19: 344-355. - doi: 10.2980/19-4-3506

Maesano M, Lasserre B, Masiero M, Tonti D, Marchetti M (2014). First mapping of the main high conservation value forests (HCVFs) at national scale. Plant Biosystems. [in press] doi: 10.1080/11263504.2014.948524

McGee GG, Kimmerer RW (2002). Forest age and management effects on epiphytic bryophyte communities in Adirondack northern hardwood forests, New York, USA. Canadian Journal of Forest Research 32: 1562-1576. - doi: 10.1139/x02-083

MCPFE (2001). Criteria and indicators for sustainable forest management of the MCPFE. Review of development and current status. In: Proceedings of the "International Expert Meeting on Monitoring, Assessment and Reporting on the Progress Towards Sustainable Forest Management 2". Yokohama (Japan), 5-8 Nov 2001, pp. 13.

MCPFE (2002). Improved pan-european indicators for sustainable forest management as adopted by the MCPFE. In: Proceedings of the "MCPFE Expert Level Meeting". Vienna (Austria) 7-8 Oct 2002, pp. 5.

MCPFE/UNECE/FAO (2007). State of world's forests 2007: the MCPFE report on sustainable forest management in Europe. Ministerial Conference on the Protection of Forests in Europe Liaison Unit Warsaw, Warsaw, Poland, pp. 247. [online] URL: http://www.fao.org/docrep/oog/ a0773e/a0773eoo.htm

McRoberts RE, Tomppo EO (2007). Remote sensing support for national forest inventories. Remote Sensing of Environment 110: 412-419. doi: 10.1016/j.rse.2006.09.034

McRoberts RE (2009). Diagnostic tools for nearest neighbors techniques when used with satellite imagery. Remote Sensing of Environment 113: 489-499. - doi: 10.1016/j.rse.2008.06.015 McRoberts R, Tomppo E, Schadauer K, Vidal C, Stahl G, Chirici G, Lanz A, Cienciala E, Winter S, Smith B (2009). Harmonizing national forest inventories. Journal of Forestry 107: 179-187. [online] URL: http://www.ingentaconnect.com/ content/saf/jof/2009/00000107/00000004/arto 0005

McRoberts RE, Cohen WB, Næsset E, Stehman SV, Tomppo EO (2010). Using remotely sensed data to construct and assess forest attribute maps and related spatial products. Scandina- vian Journal of Forest Research 25: 340-367. doi: 10.1080/02827581.2010.497496

McRoberts RE, Chirici G, Winter S, Barbati A, Corona P, Marchetti M, Hauk E, Brändli UB, Beranova J, Rondeux J, Sanchez C, Bertini R, Barsoum N, Asensio IA, Condés S, Saura S, Neagu S, Cluzeau C, Hamza N (2011). Prospects for harmonized biodiversity assessments using national forest inventory data. In: "National Forest Inventories: contributions to forest biodiversity assessments" (Chirici G, Winter S, McRoberts RE eds). Springer, Heidelberg, Germany, pp. 41-98. - doi: 10.1007/978-94-007-048243

Müller R, Krauß T, Lehner $M$, Reinartz P, Forsgren J, Rönnbäck G, Karlsson Å (2006). IMAGE2006 European coverage. Methodology and Results. DLR IMF PB, ESA, Cologne, Germany, pp. 55. [online] URL: https://earth.esa.int/pub/ ESA_DOC/Image2006-v1_01.pdf

Nel EM, Wessman CA, Veblen TT (1994). Digital and visual analysis of thematic mapper imagery for differentiating old growth from younger spruce-fir stands. Remote Sensing of Environment 48: 291-301. - doi: 10.1016/0034-4257(94) 90003-5

Nocentini S (2009). Structure and management of beech (Fagus sylvatica L.) forests in Italy. iForest 2: 105-113. - doi: 10.3832/iforo499-002

Olofsson P, Foody GM, Herold M, Stehman SV, Woodcock CE, Wulder MA (2014). Good practices for estimating are and assessing accuracy of land change. Remote Sensing of Environment 148: 42-57. - doi: 10.1016/j.rse.2014.02.015 Pan Y, Chen JM, Birdsey R, McCullough K, He L, Deng F (2010). Age structure and disturbance legacy of North American forests. Biogeosciences 7: 979-1020. - doi: 10.5194/bgd-7-979-2010

Peng C (2000). Growth and yield models for uneven-aged stands: past, present and future. Forest Ecology and Management 132: 259-279. doi: 10.1016/S0378-1127(99)00229-7

Pettenella D, Klöhn S, Brun F, Carbone F, Venzi L, Cesaro L, Ciccarese L (2005). Italy's country report. Acta Silvatica et Lignaria Hungarica 1: 383436. [online] URL: http://www.isprambiente. gov.it/files/atmosfera/italy-report.pdf

Pitkänen S (1997). Correlation between stand structure and ground vegetation: an analytical approach. Plant Ecology 131: 109-126. - doi: 10.1023/A:1009723603098

Rambo TR, Muir PS (1998). Bryophyte species associations with coarse woody debris and stand ages in Oregon. Bryologist 101: 366-376. doi: 10.1639/0007-2745(1998)101[366:BSAWCW] 2.0.CO;2

Reese H, Nilsson M, Granqvist Pahlén T, Hagner $\mathrm{O}$, Joyce $\mathrm{S}$, Tingelöf $\mathrm{U}$, Egberth $\mathrm{M}$, Olsson $\mathrm{H}$ (2003). Countrywide estimates of forest variables using satellite data and field data from the national forest inventory. Ambio 32: 542-548. doi: 10.1579/0044-7447-32.8.542

Russo D, Cistrone L, Garonna AP, Jones G (2010). Reconsidering the importance of harvested forests for the conservation of tree-dwelling bats. Biodiversity and Conservation 19: 25012515. - doi: 10.1007/s10531-010-9856-3

Santopuoli G, Lasserre B, Di Martino P, Marchetti
$M$ (2014). Dynamics of the silver fir (Abies alba Mill.) natural regeneration in a mixed forest in the central Apennine. Plant Biosystems [in press]. - doi: 10.1080/11263504.2014.948525 Schelhaas MJ, Eggers J, Lindner M, Nabuurs GJ, Pussinen A, Päivinen R, Schuck A, Van Der Werf DC, Zudin S (2007). Model documentation for the European forest information scenario model (EFISCEN 3. 1. 3). Alterra rapport 1559, EFI Technical Report 26, Joensuu, Finland, pp. 118. [online] URL: http://www.efi.int/files/attachm ents/publications/alterrarapport1559.pdf

Seidl R, Schelhaas MJ, Lexer MJ (2011). Unravelling the drivers of intensifying forest disturbance regimes in Europe. Global Change Biology 17: 2842-2852. - doi: 10.1111/j.1365-2486.2011.02452.x Seidling W, Travaglini D, Meyer P, Waldner P, Fischer R, Granke O, Chirici G, Corona P (2014). Dead wood and stand structure - relationships for forest plots across Europe. iForest 7: 269281. - doi: 10.3832/ifor1057-007

Spiecker H, Mielikaeinen K, Kohl M, Skovsgaard $P$ (1996). Growth trends in European forests: studies from 12 countries. Springer, Berlin, Germany, pp. 372.

Vanclay JK (1994). Modelling forest growth and yield: applications to mixed tropical forests. CAB International, Wallingford, UK, pp. 312. [online] URL: http://epubs.scu.edu.au/cgi/view content.cgi?article=1538\&context=esm_pubs

Vilén T, Gunia K, Verkerk PJ, Seidl R, Schelhaas MJ, Lindner M, Bellassen V (2012). Reconstructed forest age structure in Europe 1950-2010. Forest Ecology and Management 286: 203-218. doi: 10.1016/j.foreco.2012.08.048

Vuokila Y (1965). Functions for variable density yield tables of pine based on temporary sample plots. Communicationes Instituiti Forestalis Fenniae 60: 1-86.

Weiskittel AR, Hann DW, Kershaw JA, Vanclay JK (2011). Forest growth and yield modeling. Wiley-Blackwell, Chichester, UK, pp. 430. [online] URL: http://books.google.com/books? id $=M J 4 \_S 8 s r X \times 4 C$

Zhang Q, Pavlic G, Chen W, Latifovic R, Fraser R, Cihlar J (2004). Deriving stand age distribution in boreal forest using SPOT VEGETATION and NOAA AVHRR imagery. Remote Sensing of Environment 91: 405-418. - doi: 10.1016/j.rse. 2004.04.004

Zurlini G, Petrosillo I, Aretano R, Castorini I, D’Arpa S, De Marco A, Pasimeni MR, Semeraro $\mathrm{T}$, Zaccarelli N (2014). Key fundamental aspects for mapping and assessing ecosystem services: predictability of ecosystem service providers at scales from local to global. Annali di Botanica 4: 53-63. [online] URL: http://www.rspi.uniroma1. it/index.php/Annalidibotanica/article/view/11754

\section{Supplementary Material}

\section{Appendix 1}

Tab. S1 - Inverted yield equations used for forest age estimation.

Link: Frate_1529@supplo01.pdf 